\title{
Implication of $G \beta \gamma$ proteins and c-SRC tyrosine kinase in parathyroid hormone-induced signal transduction in rat enterocytes
}

\author{
Claudia Gentili, Ricardo Boland and Ana Russo de Boland \\ Departamento de Biología, Bioquímica y Farmacia, Universidad Nacional del Sur, San Juan 670, 8000 Bahia Blanca, Argentina \\ (Requests for offprints should be addressed to A R de Boland; Email: aboland@criba.edu.ar)
}

\begin{abstract}
Parathyroid hormone $(\mathrm{PTH})$ interacts in target tissues with a G protein-coupled receptor (GPCR) localized in the plasma membrane. Although activation of GPCR can elicit rapid stimulation of cellular protein tyrosine phosphorylation, the mechanism by which $G$ proteins activate protein-tyrosine kinases is not completely understood. In the present work, we demonstrate that PTH rapidly increases the activity of non-receptor tyrosine kinase c-Src in rat intestinal cells (enterocytes). The response is biphasic, the early phase is fast and transient, peaking at $30 \mathrm{~s}$ $(+120 \%)$, while the second phase progressively increases up to $5 \mathrm{~min}(+220 \%)$. The hormone activates c-Src in intestinal cells through fast changes in tyrosine phosphorylation of the enzyme. The first event in the activation of c-Src is the dephosphorylation of Tyr527 (which happens after a few seconds of PTH treatment), followed by a second event of activation with phosphorylation at Tyr416 (+twofold, $5 \mathrm{~min}$ ). Removal of external $\mathrm{Ca}^{2+}$
\end{abstract}

(EGTA, $0 \cdot 5 \mathrm{mM}$ ) and chelation of intracellular $\mathrm{Ca}^{2+}$ with 1,2-bis(2-aminophenoxy)ethane-N,N, $N^{\prime}, \mathrm{N}^{\prime}$-tetracetic acid acetoxymethyl ester (BAPTA) $(5 \mu \mathrm{M})$ suppressed Tyr527 dephosphorylation and Tyr416 phosphorylation, indicating that $\mathrm{Ca}^{2+}$ is an upstream activator of c-Src in enterocytes stimulated with PTH. The G protein subunits, Gas and $G \beta$, are associated with c-Src in basal conditions and this association increases two- to threefold in cells treated with PTH. Blocking of G $\beta$ subunits by preincubation of cells with a G $\beta$ antibody abolished hormone-dependent c-Src Tyr416 phosphorylation and ERK1/ERK2 activation. The results of this work indicate that $\mathrm{PTH}$ activates $\mathrm{c}-\mathrm{Src}$ in intestinal cells through conformational changes via $G$ proteins and calcium-dependent modulation of tyrosine phosphorylation of the enzyme, and that PTH receptor activation leads via $G \beta \gamma-c-S r c$ to the phosphorylation of the MAP kinases, ERK1 and ERK2.

Journal of Endocrinology (2006) 188, 69-78

\section{Introduction}

Parathyroid hormone (PTH) is an 84-amino-acid polypeptide hormone functioning as a major mediator of bone remodeling and as an essential regulator of calcium homeostasis (Rosenblatt et al. 1989). In rat intestinal cells (enterocytes), PTH initiates its effects by interacting with the heterotrimeric $G$ protein-coupled receptor, PTHR1 (Gentili et al. 2003b). The transduction of PTH signal through the plasma membrane of rat enterocytes involves both a Gs-mediated stimulation of adenylyl cyclase with cAMP production and protein kinase (PK) A activation (Picotto et al. 1997), and a Gq-mediated activation of phospholipase (PL) $C \beta$, leading to generation of inositol 1,4,5 trisphosphate $\left(\mathrm{IP}_{3}\right)$ and diacylglycerol, followed by activation of PKC (Massheimer et al. 2000). PTH also increases intracellular $\mathrm{Ca}^{2+}$ levels in rat enterocytes by promoting an initial acute $\mathrm{IP}_{3}$-mediated mobilization of $\mathrm{Ca}^{2+}$ from a thapsigargin-sensitive store, and a sustained phase due to $\mathrm{Ca}^{2+}$ influx through voltage-dependent $\mathrm{Ca}^{2+}$-channels (Gentili et al. 2003a). Activation of PTH seven transmembrane receptor in enterocytes also leads to tyrosine phosphorylation of a number of intracellular proteins, the most prominent being PLC $\gamma$ (Gentili et al. 2001a) and the mitogen-activated protein kinases, ERK1 and ERK2 (Gentili \& de Boland 2000) which leads to an increase in DNA synthesis (Gentili et al. 2001b). Initial studies on the mechanisms underlying $\mathrm{PTH}$ activation of the enterocyte tyrosine phosphorylation revealed that the cytosolic tyrosine kinase c-Src plays a central role in these processes, demonstrating that pharmacological inhibition of c-Src abolishes PTH-dependent PLC $\gamma$ phosphorylation, the ERK cascade activation (Gentili \& de Boland 2000, Gentili et al. 2001a) and ERK-induced enterocyte proliferation (Gentili et al. 2001b). The c-Src tyrosine kinase has been shown to regulate a diverse number of cellular effects including stimulating and inhibiting cell growth (Roche et al. 1995, Broome \& Hunter 1996), regulating cell adhesion (Parsons \& Parsons 1997, Cary et al. 2002), and regulating apoptosis (Carragher et al. 2001).

The heterotrimeric guanine nucleotide binding $(G)$ proteins control diverse biological processes by conveying 
signals from cell-surface receptors to intracellular effectors. They are a family of proteins that transduce an extracellular signal to an intracellular response via a seven helical transmembrane receptor ( $G$ protein-coupled receptor, GPCR). Upon activation, the receptor facilitates the

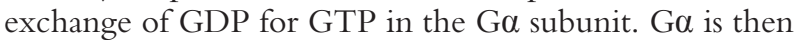
thought to dissociate from the $G \beta \gamma$ heterodimer, allowing both complexes to individually activate a number of effectors (Neer 1995, Hamm 1998). Although function was originally ascribed to the GTP-bound $\alpha$-subunit, it is now well established that the $\beta \gamma$-dimer plays active roles in the signaling process through upstream recognition of receptors and downstream regulation of effectors (Clapham \& Neer 1997). Molecular cloning has identified at least $5 \beta$ - and $12 \gamma$-subunit genes in the mouse and human genomes. Structurally, $\gamma$-subunits are the most diverse, with four subgroups that show less than 50\% identity to each other (Balcueva et al. 2000). Moreover, $\gamma$-subunits exhibit very different temporal (Morishita et al. 1999, Schuller et al. 2001) and spatial (Betty et al. 1998) patterns of expression. These characteristics suggest that $\gamma$-subunits have heterogeneous functions. Free $G \beta \gamma$ interacts with a large assortment of effector proteins, including phospholipases (Rhee \& Bae 1997), adenylyl cyclases (Sunahara et al. 1996), ion channels (Schneider et al. 1997), and $G$ protein-coupled receptor kinases (Pitcher et al. 1992). There are, however, G proteincoupled receptor responses, such as MAP kinase activation (Koch et al. 1994, Luttrell et al. 1996, 1997), receptor internalization (Liu et al. 1997, Lin et al. 1998), and organelle transport (Stow \& Heimann 1998, Jamora et al. 1999) that are mediated through the $G \beta \gamma$ subunit but which have not definitively been linked to known $G \beta \gamma$ effectors. Although activation of $G$ protein-coupled receptors can elicit rapid stimulation of cellular protein tyrosine phosphorylation, the mechanism by which G proteins activate protein-tyrosine kinases is not completely understood. In the present study, we identified $\mathrm{c}$-Src tyrosine kinase as a direct effector of $\mathrm{G}$ proteins and characterized the $G$ proteins subunits involved in the mechanism by which PTH regulates ERKs via c-Src tyrosine kinase.

\section{Materials and Methods}

\section{Chemicals}

Synthetic rat $\mathrm{PTH}(1-34)$, immobilon $\mathrm{P}$ (polyvinylidene difluoride, PVDF) membranes, enolase and protein A-Sepharose were from Sigma Chemical Co. (St Louis, MO, USA). Rabbit polyclonal anti-phosphotyrosine antibody, rabbit anti-phospho c-Src Y527 and Y416 antibodies were obtained from Cell Signaling Technology Inc. (Beverly, MA, USA). Anti-PLC $\gamma$, anti-P-ERK, antiERK and anti-c-Src antibodies were from Santa Cruz Biotechnology (Santa Cruz, CA, USA). G protein antibodies were generously provided by Dr Maria Julia Marinissen (NIH, MD, USA). Secondary antibody goat anti-rabbit horseradish peroxidase (HRP)-conjugated IgG and the Super Signal CL-HRP substrate system for enhanced chemiluminiscence (ECL) were obtained from Amersham Corp. (Arlington Heights, IL, USA). $\left[\gamma{ }^{32} \mathrm{P}\right]$ ATP $(3000 \mathrm{Ci} / \mathrm{mmol})$ was from New England Nuclear (Chicago, IL, USA). All other reagents were of analytical grade.

\section{Animals}

Three-month-old male Wistar rats were fed with standard rat food $(1 \cdot 2 \% \mathrm{Ca}, 1 \cdot 0 \%$ phosphorus), with water available ad libitum, and were maintained on a $12 \mathrm{~h}$ light- $12 \mathrm{~h}$ darkness cycle. Animals were killed by cervical dislocation. Animals were maintained in accordance with the NIH Guide for the Care and Use of Laboratory Animals (1996 (7th edn) Washington, DC: National Academy Press, aka National Research Council Guide).

\section{Isolation of duodenal cells}

Duodenal cells were isolated as described previously (Massheimer et al. 1994). The method employed yields preparations containing only highly absorptive epithelial cells that are devoid of cells from the upper villus or crypt (Weiser 1973). The duodenum was excised, washed and trimmed of adhering tissue. The intestine was slit lengthwise, cut into small segments $(2 \mathrm{~cm}$ length $)$ and placed into solution A: $96 \mathrm{mM} \mathrm{NaCl}, 1.5 \mathrm{mM} \mathrm{KCl}, 8 \mathrm{mM}$ $\mathrm{KH}_{2} \mathrm{PO}_{4}, 5 \cdot 6 \mathrm{mM} \mathrm{Na}_{2} \mathrm{HPO}_{4}, 27 \mathrm{mM}$ Na citrate, $\mathrm{pH} 7 \cdot 3$, for $10 \mathrm{~min}$ at $37^{\circ} \mathrm{C}$. The solution was discarded and replaced with solution $\mathrm{B}$ (isolation medium): $154 \mathrm{mM}$ $\mathrm{NaCl}, 10 \mathrm{mM} \mathrm{NaH}_{2} \mathrm{PO}_{4}, 1.5 \mathrm{mM}$ EDTA, $0.5 \mathrm{mM}$ dithiothreitol (DTT), $5.6 \mathrm{mM}$ glucose, $\mathrm{pH} 7 \cdot 3$, for $15 \mathrm{~min}$ at $37^{\circ} \mathrm{C}$ with vigorous shaking. The cells were sedimented by centrifugation at $155 \times \boldsymbol{g}$ for $10 \mathrm{~min}$, washed twice with $154 \mathrm{mM} \mathrm{NaCl}, 10 \mathrm{mM} \mathrm{NaH}{ }_{2} \mathrm{PO}_{4}, 5.6 \mathrm{mM}$ glucose, $\mathrm{pH} 7 \cdot 4$ and resuspended in the incubation medium (solution D): $154 \mathrm{mM} \mathrm{NaCl}, 5 \mathrm{mM} \mathrm{KCl}, 1 \mathrm{mM}$ $\mathrm{Na}_{2} \mathrm{HPO}_{4}, 1 \mathrm{mM} \mathrm{MgCl}, 10 \mathrm{mM}$ NaMOPS $\mathrm{pH} 7 \cdot 4$, $5.6 \mathrm{mM}$ glucose, $0.5 \%$ BSA, $1 \mathrm{mM} \mathrm{CaCl}, 2.5 \mathrm{mM}$ glutamine. All the above steps were performed under a $95 \% \mathrm{O}_{2}: 5 \% \mathrm{CO}_{2}$ atmosphere using oxygenated solutions. The enterocytes were used between 20 and $60 \mathrm{~min}$ after their isolation. Cell viability was assessed by trypan blue exclusion in dispersed cell preparations; $85-90 \%$ of the cells were viable for at least $150 \mathrm{~min}$.

\section{In vitro treatments}

Isolated duodenal cells were pre-equilibrated in solution D for $15 \mathrm{~min}$ and then exposed for short intervals (15 s-10 min) to PTH $\left(10^{-8} \mathrm{M}\right)$. After treatment, enterocytes were lysed in $50 \mathrm{mM}$ Tris- $\mathrm{HCl}(\mathrm{pH} \mathrm{7} 4), 150 \mathrm{mM}$ 
$\mathrm{NaCl}, 2 \mathrm{mM}$ EGTA, $25 \mathrm{mM} \mathrm{NaF}, 0.2 \mathrm{mM}$ sodium orthovanadate, $1 \mathrm{mM}$ phenylmethylsulfonyl fluoride, $2 \mu \mathrm{g} / \mathrm{ml}$ leupeptin, $2 \mu \mathrm{g} / \mathrm{ml}$ aprotinin, $0 \cdot 25 \%$ sodium deoxycholate and 1\% NP40. Insoluble material was pelleted in a microcentrifuge at 14000 r.p.m. for $10 \mathrm{~min}$. The protein content of the clear lysates was determined according to the method of Bradford (1976).

\section{Immunoprecipitation}

Lysate aliquots $(500-700 \mu \mathrm{g}$ protein) were incubated overnight at $4{ }^{\circ} \mathrm{C}$ with anti-phosphotyrosine antibody, followed by precipitation of the complexes with protein A conjugated with Sepharose. The immune complexes were washed three times with cold immunoprecipitation buffer (10 mM Tris-HCl, pH 7•4, $150 \mathrm{mM} \mathrm{NaCl}, 1$ mM EGTA, $1 \mathrm{mM}$ EDTA, $0.2 \mathrm{mM}$ PMSF, $0.2 \mathrm{mM}$ sodium orthovanadate, $1 \%$ Triton $\mathrm{X}-100$ and $1 \% \mathrm{NP} 40$ ), two times with PBS and then subjected to Western blot analysis.

\section{Co-immunoprecipitation}

Co-immunoprecipitation assays were performed under native conditions in order to preserve protein-protein associations. After hormone treatment, cells were lysed $\left(15 \mathrm{~min}\right.$ at $\left.4{ }^{\circ} \mathrm{C}\right)$ in $50 \mathrm{mM}$ Tris- $\mathrm{HCl}, \mathrm{pH} 7 \cdot 4,150 \mathrm{mM}$ $\mathrm{NaCl}, 3 \mathrm{mM} \mathrm{KCl}, 0.5 \mathrm{mM}$ EDTA, $0.2 \mathrm{mM} \mathrm{Na}_{3} \mathrm{VO}_{4}$ (OV), $1 \mathrm{mM} \mathrm{NaF}, 1 \mathrm{mM}$ PMSF, $6 \mu \mathrm{g} / \mathrm{ml}$ leupeptin, $8 \mu \mathrm{g} / \mathrm{ml}$ aprotinin, and $1 \%$ Tween-20. Lysates were clarified by centrifugation $(14000 \times \boldsymbol{g}, 10 \mathrm{~min})$ and immunoprecipitation of the supernatants was performed with anti-G $\alpha$ s, anti-G $\beta$ or anti-c-Src antibodies, the precipitated immunocomplexes were washed and processed as described above. To confirm co-inmmunoprecipitation of both proteins, immunoprecipitation and immunoblotting were performed with the same antibodies used in reverse order.

\section{SDS-PAGE and immunoblotting}

Immunoprecipitated proteins (or lysate proteins) dissolved in Laemmli sample buffer were separated on SDSpolyacrylamide (10\%) gels (Laemmli 1970) and electrotransferred to polyvinylidene difluoride (PVDF) membranes. The membranes were blocked for $2 \mathrm{~h}$ at room temperature in TBST $(50 \mathrm{mM}$ Tris- $\mathrm{HCl}$, $\mathrm{pH} 7 \cdot 4,200 \mathrm{mM} \mathrm{NaCl}, 1 \%$ Tween 20 containing 1\% dry milk). Anti-phospho c-Src (Tyr527), anti-phospho c-Src (Tyr416), anti-c-Src, anti- phospho ERKs (p42 and p44 isoforms), anti-Gas, or anti-G $\beta$ antibodies were allowed to react with the membrane overnight at $4{ }^{\circ} \mathrm{C}$. Next, the membranes were washed three times in TBST, incubated with a 1:10 000 dilution of peroxidase-conjugated antirabbit secondary antibody for $1 \mathrm{~h}$ at room temperature and washed three additional times with TBST. The membranes were then visualized using an enhanced chemiluminescent technique, according to the manufacturer's instructions. Images were obtained with a model GS-700 Imaging Densitometer from Bio-Rad (Hercules, CA, USA) by scanning at $600 \mathrm{dpi}$ and printing at the same resolution. Bands were quantified using the Molecular Analyst program (Bio-Rad).

\section{Measurement of c-Src kinase activity}

Cell lysates $(700 \mu \mathrm{g}$ protein) were prepared followed by immunoprecipitation of c-Src as described above. After three washes with immunoprecipitation buffer and two washes with kinase buffer $(50 \mathrm{mM}$ Tris- $\mathrm{HCl}, \mathrm{pH} 7 \cdot 4$, $5 \mathrm{mM} \mathrm{MgCl}_{2}, 1 \mathrm{mM}$ DTT, $0 \cdot 1 \mathrm{mM}$ sodium orthovanadate), the immune complexes were incubated at $30{ }^{\circ} \mathrm{C}$ for $10 \mathrm{~min}$ in kinase buffer ( $30 \mu \mathrm{l} / \mathrm{sample})$ containing enolase as an exogenous substrate for $\operatorname{Src}(2 \cdot 5 \mu \mathrm{g} /$ assay $), 50 \mu \mathrm{M}$ ATP and $\left[\gamma-{ }^{32} \mathrm{P}\right]$ ATP $(2 \mu \mathrm{Ci} / \mathrm{assay})$. To terminate the reaction, the phosphorylated product was separated from free isotope on ion-exchange phosphocellulose filters (Whatman P-81). Papers were immersed immediatly onto ice-cold $75 \mathrm{mM} \mathrm{H}_{3} \mathrm{PO}_{4}$, washed $(1 \times 5 \mathrm{~min}, 3 \times 20 \mathrm{~min})$ and counted in a scintillation counter.

\section{Measurement of adenylyl cyclase activity}

Adenylyl cyclase activity was determined by measuring the cAMP generated after hormonal treatment of microsomal membranes (Farndale et al. 1994). Microsomal membranes were isolated by centrifugation at 100000 $\times \boldsymbol{g}(60 \mathrm{~min})$. Microsomal protein $(75 \mu \mathrm{g})$ was incubated in $500 \mu \mathrm{M}$ ATP, $10 \mathrm{mM} \mathrm{MgCl} 2,10 \mathrm{mM}$ phosphocreatine, $50 \mathrm{U} / \mathrm{ml}$ creatine kinase, $100 \mu \mathrm{M}$ isobutylxanthine, $1 \mathrm{mM}$ DTT, $10 \mathrm{mM}$ Tris-HCl, $\mathrm{pH} 7 \cdot 4$, for $3 \mathrm{~min}$ at $30^{\circ} \mathrm{C}$. Treatment was stopped by the addition of perchloric acid (6\%) followed by centrifugation. Cyclic AMP was measured in the supernatant by a protein binding assay (Tovey et al. 1974) using a commercial kit.

\section{Statistical evaluation}

Statistical significance of the data was evaluated using Student's $t$-test (Snedecor \& Cochran 1967) and probability values below $0.05(P<0.05)$ were considered significant. Results are expressed as means \pm standard deviation (s.D.) from the indicated set of experiments.

\section{Results}

To evaluate whether the tyrosine kinase c-Src is a downstream effector of $G$ proteins in the PTH signaling mechanism in rat intestinal cells, we first investigated the effect of the hormone on c-Src kinase activity. To that end, the enzyme from lysates of rat enterocytes exposed for different times to PTH $\left(10^{-8} \mathrm{M}\right)$ was immunoprecipitated with a highly specific anti-c-Src monoclonal 


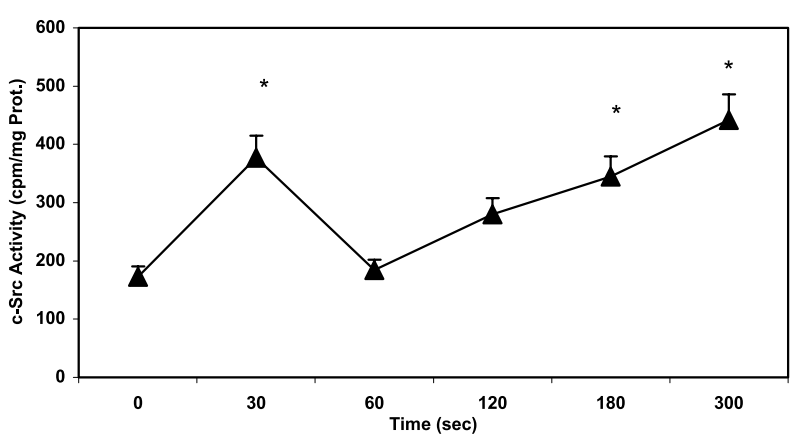

Figure 1 Time-course of PTH stimulation of c-Src kinase activity. Rat enterocytes were incubated in the presence of PTH(1-34) $\left(10^{-8} \mathrm{M}\right)$ for the indicated times. Immunoprecipitation of c-Src and assay of c-Src tyrosine kinase activity using $\left[\gamma_{-}{ }^{32} \mathrm{P}\right]$ ATP and enolase as exogenous substrate were carried out as detailed in Materials and Methods. Results are the average of three independent experiments performed in triplicate $\pm S . D{ }^{*} P<0 \cdot 05$. Prot., protein.

antibody and then $\left[\gamma_{-}{ }^{32} \mathrm{P}\right] \mathrm{ATP}$ and enolase, acting as exogenous c-Src substrate, were added. As shown in Fig. 1, PTH caused a time-dependent increase in Src kinase activity in rat enterocytes. Phosphorylation of the c-Src substrate is biphasic, with an early phase peaking at $30 \mathrm{~s}(+120 \%)$ and a second phase gradually increasing up to $5 \mathrm{~min}$ of treatment with the hormone $(+220 \%)$. No time-dependent changes in c-Src activity were observed under basal conditions (data not shown). We then investigated PTH-induced changes in tyrosine phosphorylation of c-Src. Enterocytes were treated with PTH $\left(10^{-8} \mathrm{M}, 30 \mathrm{~s}-5 \mathrm{~min}\right)$ and cell lysates were immunoprecipitated with anti-P tyrosine antibody, followed by Western blotting with a specific anti-cSrc antibody. As shown in Fig. 2, PTH increased the level of tyrosine phosphorylation of c-Src with a kinetics roughly similar to that found for the increase in kinase activity. Then we monitored the phosphorylation state of Tyr527 and Tyr416 of c-Src. To that end, enterocytes were exposed to $10^{-8} \mathrm{M}$ PTH (15 s-10 min), followed by Western blot analysis of cell lysates with anti-c-Src-phospho Tyr527 and anti-c-Src-phospho Tyr416. Total c-Src was measured in the same immunoblot by stripping the membrane and reincubating with anti-c-Src antibody. As shown in Fig. 3A, PTH transiently induces the dephosphorylation of Tyr527 at $15 \mathrm{~s}$ (- twofold), and increases the phosphorylation on Tyr416 of c-Src, with maximal effects at $5 \mathrm{~min}$ (+threefold) (Fig. 3B).

The relationship of the rise in intracellular $\mathrm{Ca}^{2+}$ by PTH leading to Src activation is not defined. We have previously found that PTH increases cytosolic $\mathrm{Ca}^{2+}$ levels $\left[\mathrm{Ca}^{2+}\right]_{\mathrm{i}}$ in rat enterocytes, which involves $\mathrm{Ca}^{2+}$ mobilization from endogenous stores followed by cation influx from the extracellular millieu (Picotto et al. 1997, Gentili et al. 2003a). To evaluate the contributions of intracellular and extracellular $\mathrm{Ca}^{2+}$ pools, PTH-dependent changes in

\section{P-c-Src $(\cong 60 \mathrm{KDa})$

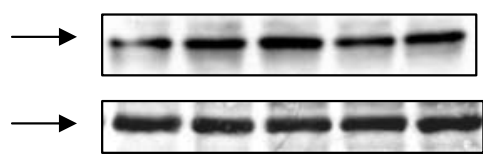 \\ $\begin{array}{lllll}0 & 15 & 30 & 60 & 180\end{array}$ Time (sec)}

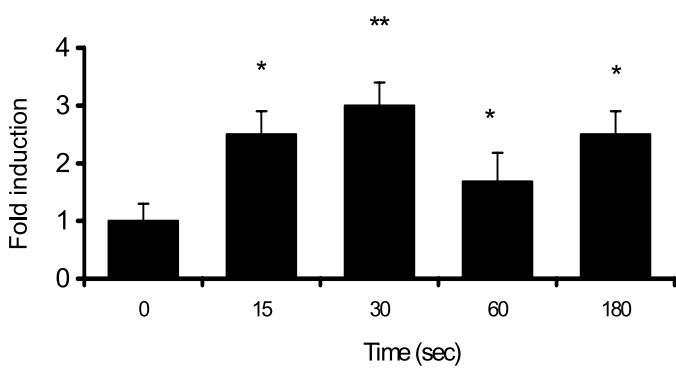

Figure 2 PTH stimulates c-Src tyrosine phosphorylation. Enterocytes were exposed to $10^{-8} \mathrm{M}$ PTH(1-34) for the indicated times. Cell lysates were immunoprecipitated with anti-P-tyrosine antibody, and the c-Src tyrosine phosphorylation state was assayed by immunoblotting with anti-c-Src antibody. A representative immunoblot and densitometric analysis of changes in c-Src tyrosine phosphorylation from three immunoblots are shown. ${ }^{\star} P<0 \cdot 05,{ }^{*} P P<0 \cdot 025$. Blotted membranes shown were stained with Coomasie brilliant blue in order to evaluate the equivalence of protein content among the different experimental conditions.

the tyrosine phosphorylation/dephosphorylation of c-Src were examined in a $\mathrm{Ca}^{2+}$-free medium (EGTA, $0 \cdot 5 \mathrm{mM}$ ), and after chelating intracellular $\mathrm{Ca}^{2+}$ with 1,2-bis(2-aminophenoxy)ethane-N,N, $\mathrm{N}^{\prime}, \mathrm{N}^{\prime}$-tetracetic acid tetrakis (BAPTA-AM) $(5 \mu \mathrm{M})$. As shown in Fig. 4A, BAPTA-AM fully suppressed PTH-dependent c-Src Tyr416 phosphorylation. In the presence of EGTA, the phosphorylation of this residue is also abolished, except at $1 \mathrm{~min}$, the latter suggesting that the PTH-stimulated release of calcium from intracellular stores is responsible for the early effect of PTH on c-Src activation. Chelation of extracellular or intracellular $\mathrm{Ca}^{2+}$ also inhibited hormone-dependent rapid dephosphorylation of c-Src Tyr527 (Fig. 4B). These results point to a role for $\mathrm{Ca}^{2+}$ as an upstream activator of $\mathrm{c}-\mathrm{Src}$ in rat enterocytes exposed to PTH.

To further explore PTH-signal transduction in enterocytes, we initially determined whether G proteins are upstream mediators of PTH-induced c-Src activation. To investigate whether there is a direct interaction between c-Src and $G$ proteins, we performed co-immunoprecipitation studies with Gas and G $\beta$ subunits in PTHstimulated enterocytes. As shown in Fig. 5, association of both subunits to c-Src was clearly detectable under basal conditions and stimulation with PTH significantly increased the formation of the complex. The hormone induces the greatest association of the kinase with Gas and $\mathrm{G} \beta$ at 30 and 15 s respectively. Similar results were obtained when the antibodies were used in reverse order 


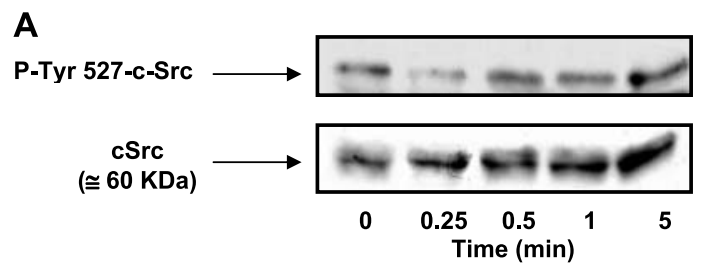

B
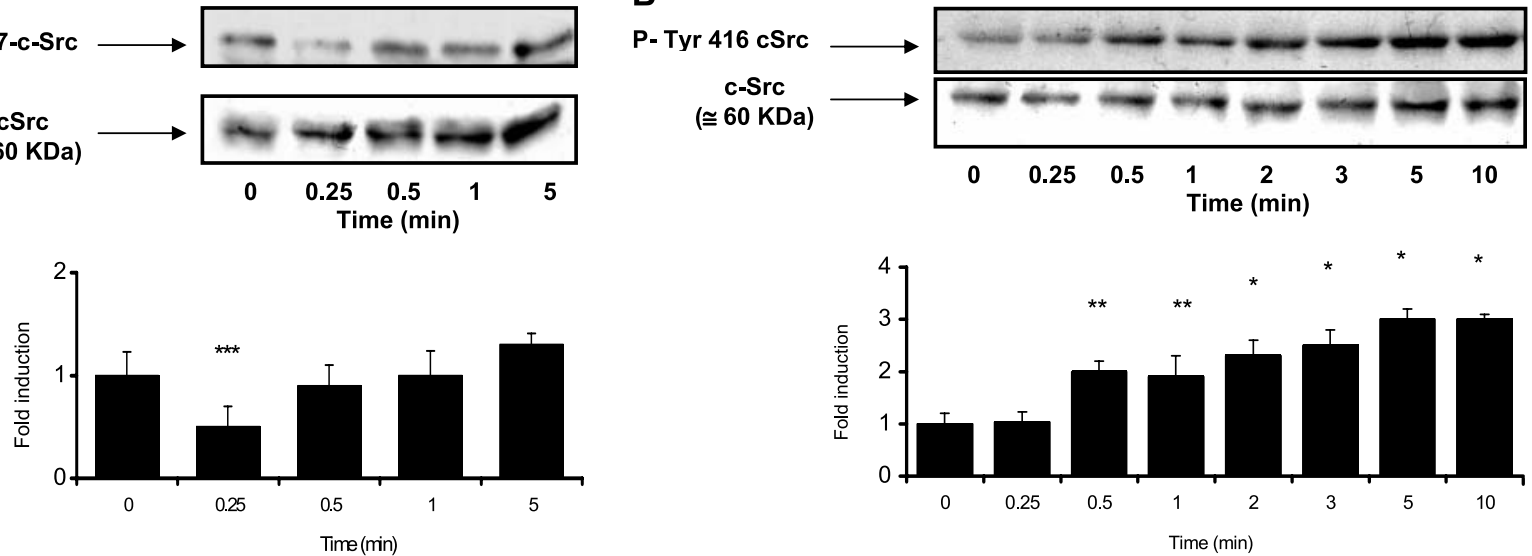

Figure 3 PTH induces c-Src Tyr527 dephosphorylation and Tyr416 autophosphorylation. Enterocytes were exposed to $10^{-8} \mathrm{M}$ $\mathrm{PTH}(1-34)$ for the indicated times. The c-Src tyrosine phosphorylation state was assayed in cell lysates by immunoblotting with anti-c-Src-phospho (P)-Tyr527 (A) and anti-c-Src-P-Tyr416 (B) antibodies as described in Materials and Methods. A representative immunoblot and densitometric analysis of changes in c-Src tyrosine phosphorylation from three immunoblots are shown; ${ }^{*} P<0 \cdot 05$, ${ }^{* *} P<0 \cdot 025,{ }^{* * *} P<0 \cdot 01$. Blotted membranes shown were re-probed with anti-c-Src antibody in order to evaluate the equivalence of c-Src kinase content among the different experimental conditions.

(not shown). These results suggest that $\mathrm{G}$ proteins may be required for $\mathrm{PTH}$-induced $\mathrm{c}-\mathrm{Src}$ activation. It is likely that cSrc association with $G$ protein subunits changes the enzyme conformation leading to increased accessibility of the active site to substrates. It has been reported that direct $\mathrm{G}$ protein regulation of $\mathrm{c}-\mathrm{Src}$ does not involve the dephosphorylation of Tyr527 (Ma et al. 2000). Therefore, in an attempt to further evaluate whether PTH-induced G
protein-Src association stimulates the PTH-mediated increase in c-Src Tyr416 autophosphorylation, enterocyte homogenates were preincubated on ice for $10 \mathrm{~min}$ in the presence of anti-G $\beta$ or anti-G $\alpha$ s antibodies, followed by exposure to $10^{-8} \mathrm{M} \mathrm{PTH}(1-34)$ for $5 \mathrm{~min}$. Proteins were resolved by electrophoresis, electroblotted into PVDF membranes and incubated with anti-c-Src-phospho Tyr416. In order to evaluate the equivalence of c-Src
A
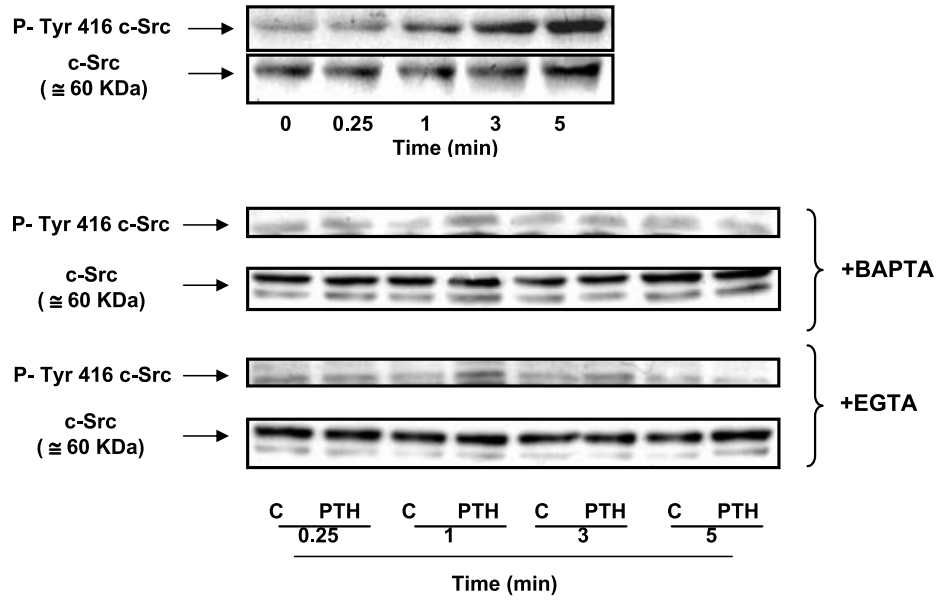

B
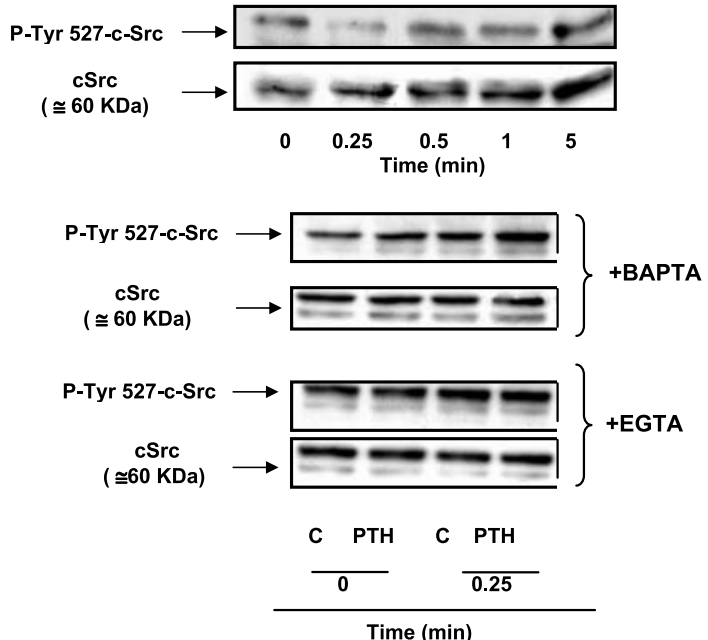

Figure $4 \mathrm{Ca}^{2+}$ dependence of PTH-induced c-Src Tyr416 phosphorylation and Tyr527 dephosphorylation. Enterocytes were exposed to $10^{-8} \mathrm{M} \mathrm{PTH}(1-34)$ for the indicated times in the presence or absence of EGTA $(0.5 \mathrm{mM})$ or BAPTA-AM (5 $\left.\mu \mathrm{M}\right)$. Cell lysates were obtained and comparable aliquots of lysate proteins were separated by SDS-PAGE followed by Western blotting with anti-c-Src-phospho-Tyr416 (A) or anti-c-Src-phospho-Tyr527 (B) antibodies. Blotted membranes shown were re-probed with anti-c-Src antibody in order to evaluate the equivalence of c-Src kinase content among the different experimental conditions. Representative immunoblots from 3 independent experiments are shown. 


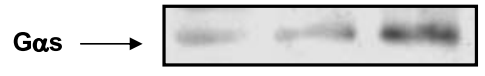

IP: anti-cSrc

IB: anti- Gas

$\mathbf{G} \beta$

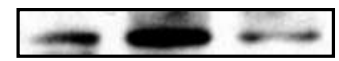

IP: anti- cSrc

IB: anti- $\mathbf{G \beta}$

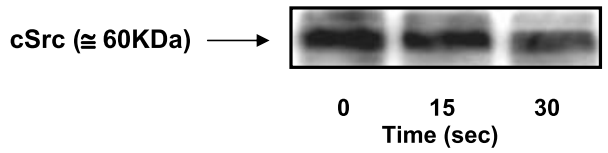

IP: anti- cSrc

IB: anti- cSrc

Figure 5 Interaction of G $\alpha$ s and G $\beta$ with c-Src in enterocytes stimulated with PTH. Enterocytes were exposed to $10^{-8} \mathrm{M}$

PTH(1-34) for the indicated times. Cell lysates were obtained, c-Src was immunoprecipitated (IP) with anti-c-Src monoclonal antibody under native conditions, resolved onto 10\% SDS-PAGE gels and then immunoblotted (IB) with anti-G $\alpha$ s or anti-G $\beta$ antibodies as described in Materials and Methods. Representative immunoblots from 3 independent experiments are given.

kinase content among the different experimental conditions, blotted membranes were re-probed with anti-Src antibody. When enterocyte homogenates were preincubated with anti-G $\beta$ antibody followed by a brief exposure to PTH, the effect of the hormone on c-Src Tyr416 phosphorylation was abolished (Fig. 6). Incubation with anti-Gas did not alter the PTH-dependent increase in c-Src Tyr416 phosphorylation. In rat enterocytes, we have previously reported that PTH activates the MAP kinases, ERK1 and ERK2, by a mechanism dependent on c-Src, the adenylyl cyclase pathway and $\mathrm{Ca}^{2+}$ (Gentili \& de Boland 2000, Gentili et al. 2001b). To examine whether G $\beta \gamma$ and Gas subunits could mediate PTH-dependent activation of ERKs, we determined whether the hormone effect is sensitive to antibody blockade of these $G$ protein subunits. To that end, enterocyte homogenates were preincubated in the presence or absence of anti-G $\beta$ or anti-Gas antibodies followed by a brief exposure to $10^{-8} \mathrm{M}$ PTH(1-34). Then, cell lysates were probed with an anti-phospho ERKs antibody, which recognizes both the 42 and $44 \mathrm{kDa}$ species. As shown in Fig. 7, and in agreement with our previous results (Gentili \& de Boland 2000, Gentili et al. 2001b), PTH induces a marked increase in the phosphorylation of both isoforms. Hormone-dependent ERK1 and ERK2 tyrosine phosphorylation was sensitive to antibody treatment of $G \beta$ subunits, suggesting that c-Src via the dimer G $\beta \gamma$ activates the mitogen-activated protein kinases in cells stimulated with PTH. Antibody blockade of Gas had no effect on PTH-dependent increase in ERK1 and ERK2 phosphorylation. The efficacy of the antibody against Gas was tested by evaluating its effects on adenylyl cyclase activity. As shown in Table 1 , incubation of microsomal membranes with PTH $\left(10^{-8} \mathrm{M}\right)$ induced a $200 \%$ increase in adenylyl cyclase activity, an effect that was not seen in membranes preincubated with anti-Gas.
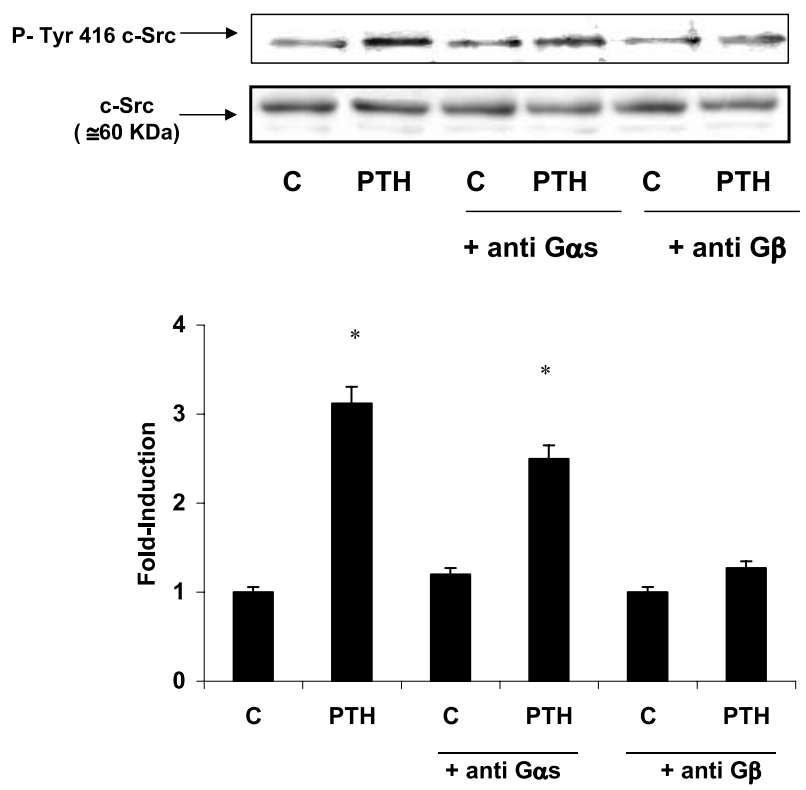

Figure 6 Inhibition of PTH-dependent c-Src Tyr416 autophosphorylation by enterocyte treatment with anti-G $\beta \gamma$ antibody. Enterocytes isolated from 3-month-old rats were homogenized and preincubated on ice for $10 \mathrm{~min}$ in the presence

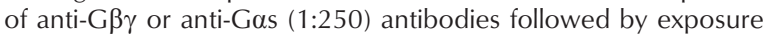
to $10^{-8} \mathrm{M}$ PTH(1-34) for 5 min. Proteins were resolved by electrophoresis, electroblotted into PVDF membranes and incubated with anti-c-Src-phospho-Tyr416 antibody as indicated in Materials and Methods. Blotted membranes shown were re-probed with anti-c-Src antibody in order to evaluate the equivalence of c-Src kinase content among the different experimental conditions. Representative immunoblot and quantification by scanning volumetric densitometry of blots from 3 independent experiments are shown; averages \pm S.D are given. ${ }^{*} P<0 \cdot 05$.

\section{Discussion}

c-Src kinase activity could be modulated by tyrosine phosphorylation and conformational changes that affect the intramolecular interactions. The kinase activity of c-Src is maintained at a low basal level by two intramolecular interactions, one is between the $\mathrm{SH} 3$ domain and the linker (between the $\mathrm{SH} 2$ domain and the kinase domain) and the other is between the SH2 domain and the phosphorylated tyrosine residue 527 (Tyr527) in the carboxyl-terminal tail (Xu et al. 1997). The tyrosine kinase Csk phosphorylates Tyr527, repressing the kinase activity of c-Src to generate a downregulated state (Brown \& Cooper 1996). In addition, autophosphorylation of Tyr416 at the activation loop is a critical step leading to full activation of $\mathrm{c}-\mathrm{Src}$ tyrosine kinase activity. In the active state, the activation loop swings away from the entrance of the catalytic cleft, allowing access of the substrate to the active site. Phosphorylation of Tyr416 has been proposed to stabilize this extended conformation and activate kinase activity ( $\mathrm{Xu}$ et al. 1999). 


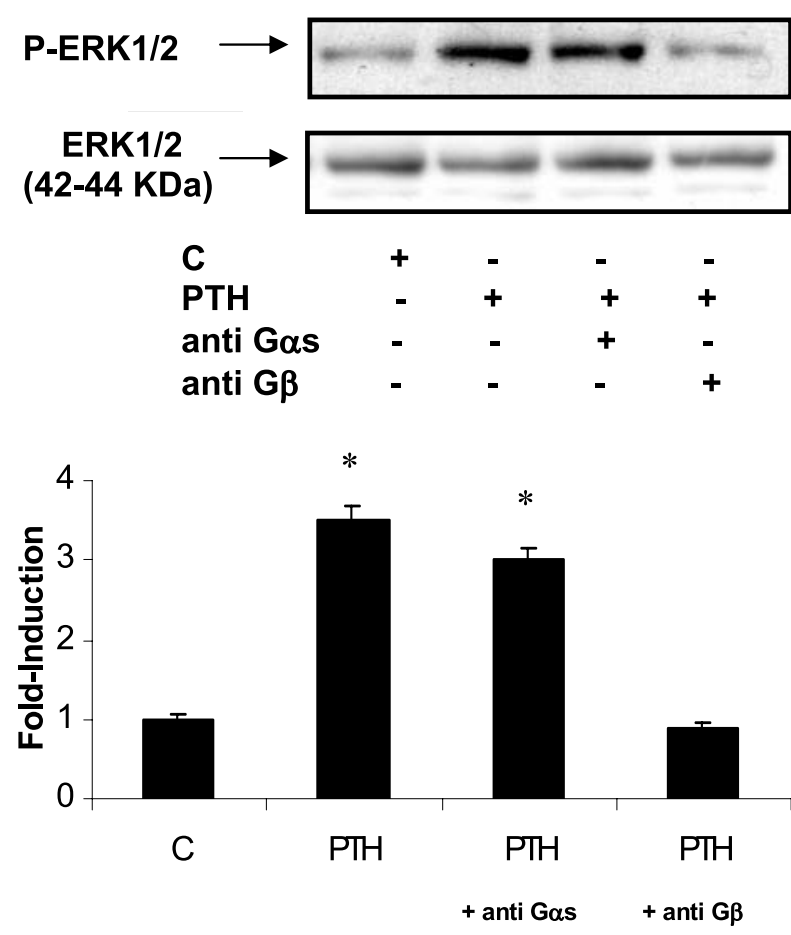

Figure $7 \mathrm{G} \beta \gamma$ subunits mediate the early phosphorylation of ERK1/2 in enterocytes stimulated with PTH. Enterocytes isolated from 3-month-old rats were homogenized and preincubated on ice for $10 \mathrm{~min}$ in the presence of anti-G $\beta \gamma$ or anti-Gas (1:250) antibodies followed by exposure to $10^{-8} \mathrm{M} \mathrm{PTH}(1-34)$ for $1 \mathrm{~min}$. Proteins were resolved by electrophoresis, electroblotted into PVDF membranes and incubated with anti-phospho ERK 1/2 antibody as indicated in Materials and Methods. Blotted membranes shown were re-probed with anti-ERK antibody in order to evaluate the equivalence of ERK kinase content among the different experimental conditions. A representative Western blot and quantification by scanning volumetric densitometry of blots from 3 independent experiments are shown; averages \pm S.D are given. ${ }^{*} P<0 \cdot 025$.

In the present work, we demonstrate, for the first time, that PTH rapidly increases, in a biphasic manner, the activity of non-receptor tyrosine kinase $\mathrm{c}-\mathrm{Src}$ in rat intestinal cells. The biphasic nature of c-Src activity has also been observed in rat colonocytes stimulated with the steroid hormone $1 \alpha, 25(\mathrm{OH})_{2}$-vitamin $\mathrm{D}_{3}$ (Khare et al. 1997). The hormone activates $\mathrm{c}-\mathrm{Src}$ in intestinal cells through fast changes in tyrosine phosphorylation of the enzyme. The first event in the activation of c-Src is the dephosphorylation of Tyr527 (which happens after a few seconds of PTH treatment), which rapidly undergoes re-phosphorylation most likely catalyzed by Csk as discussed above. This is followed by a second event of activation related to the phosphorylation at Tyr416. In line with these observations, there is evidence demonstrating that PTH activates c-Src in osteoblastic cells through changes in tyrosine phosphorylation (Izbicka et al. 1994). Our results show that removal of external $\mathrm{Ca}^{2+}$ and
Table 1 Effect of anti-Gas antibody on PTH-dependent adenylyl cyclase activity. Data are presented in $\mathrm{pmol} \mathrm{cAMP} / \mathrm{mg}$ protein $/ \mathrm{min}$ and in percentage of the stimulation in respect to control values (in parentheses). Results are the mean \pm S.D. of three independent experiments performed in quadruplicate

\section{cAMP levels \\ $\mathrm{pmol} / \mathrm{mg}$ protein $/ \mathrm{mg}$ )}

$\begin{array}{ll}\text { Control } & 2 \cdot 90 \pm 0 \cdot 52 \\ \text { PTH } & 9 \cdot 05 \pm 0 \cdot 81(+212 \%)^{*} \\ \text { Anti Gas } & 3 \cdot 02 \pm 0 \cdot 40 \\ \text { PTH+anti Gas } & 3 \cdot 14 \pm 0 \cdot 67(+8 \%)\end{array}$

Enterocyte microsomal membranes isolated from 3 month-old rats, were homogenized and preincubated on ice for $10 \mathrm{~min}$ in the presence or absence of anti-Gas (1:250) antibody followed by exposure to $10^{-8} \mathrm{M}$ PTH(1-34) for 2 min. Adenylyl cyclase activity was determined as described under Materials and Methods.

${ }^{*} P<0 \cdot 005$ with respect to control.

chelation of intracellular $\mathrm{Ca}^{2+}$ suppressed Tyr527 dephosphorylation and Tyr416 phosphorylation, indicating that $\mathrm{Ca}^{2+}$ is an upstream activator of $\mathrm{c}$-Src in enterocytes stimulated with PTH. Extracellular $\mathrm{Ca}^{2+}$ has been shown to be required for the activation of the Src kinase pathways in pancreatic acinar cells (Tsunoda et al. 1996). Furthermore, Src family kinases have been implicated in the control of receptor-operated $\mathrm{Ca}^{2+}$ influx in various cell types (Niklinska et al. 1992, Lee et al. 1993, Bonaccorsi et al. 1995, Fleming et al. 1995). Of interest, in colonic smooth muscle cells, the biphasic activation of ceramideinduced Src kinase activity was shown to be dependent on extracellular $\mathrm{Ca}^{2+}$ in the second, sustained phase of activation (Ibitayo et al. 1998).

c-Src family tyrosine kinases emerged to play a role in heterotrimeric $\mathrm{G}$ protein signaling. There is evidence suggesting the importance of c-Src in GPCR-signal transduction pathways, but the biochemical mechanisms used by $\mathrm{G}$ proteins to activate c-Src remains largely elusive. Recent studies demonstrated that Gas and Gai directly stimulate the kinase activity of the downregulated c-Src and found that activated $G$ proteins interact with the kinase domain of c-Src (Ma et al. 2000). Our results indicate that the $G$ protein subunits, $G \alpha$ s and $G \beta$, are associated with c-Src in basal conditions and this association increases two- to threefold in rat intestinal cells treated with PTH. Blocking of G $\beta$ subunits by preincubation of cells with a G $\beta$ antibody abolished hormonedependent c-Src Tyr416 phosphorylation, indicating that $\mathrm{c}-\mathrm{Src}$ is a down effector of $\mathrm{G} \beta \gamma$ complexes. In line with this observation, it has been reported that $G \beta \gamma$ subunits, when overexpressed in COS-7 cells, increased (by $\sim$ twofold) c-Src Tyr416-autophosphorylation (Luttrell et al. 1996). Moreover, in other $G$ protein signaling systems, G $\beta \gamma$ plays significant roles in downstream effector activation (Clapham \& Neer 1997). 


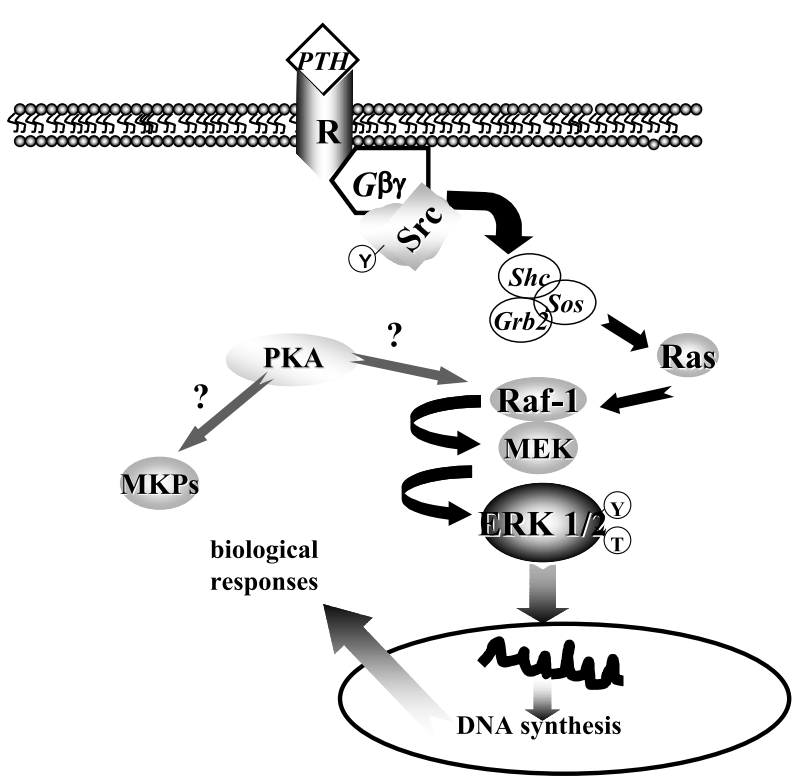

Figure $8 \mathrm{~A}$ model for the stimulation of the ERK pathways upon binding of PTH to its G protein-coupled seven transmembrane receptor in rat enterocytes. $\mathrm{PTH}$, upon binding to its seven transmembrane receptor, activates the receptor-coupled G $\beta \gamma$ protein subunits that associate and activate c-Src. Then, c-Src kinase creates $\mathrm{SH} 2$ domain binding motifs and an Shc-, Grb2-, and Sos-containing complex is formed to activate Ras and, in turn, Raf- 1 . The increase in Raf- 1 activity is subsequently transduced through the phosphorylation of the MEK-ERK module. PKA positively regulates the ERK pathway, but whether it does so through Raf- 1 activation or inhibition of MAP kinase phosphatases (MKPs) is not known at present. $\mathrm{Y}$, tyrosine; $\mathrm{T}$, threonine.

There is increasing evidence suggesting that Src tyrosine kinases have a pivotal role in the regulation of various cellular processes (Erpel \& Courtneidge 1995). Members of this family are thought to be involved in signal transduction mechanisms linked to the mitogen-activated protein kinases (ERK1 and ERK2) cascade underlying the regulation of cell proliferation and differentiation by agonists of receptor tyrosine kinases or heterotrimeric $G$ protein-coupled receptors (Marshall 1995). While the tyrosine kinase growth factor receptors transmit signals to ERKs in a well defined multistep process, the stimulation of ERK activity by $\mathrm{G}$ protein-coupled receptors may be mediated by different classes of $\mathrm{G}$ proteins, including Gs, Gi, G $\alpha \mathrm{q} / 11, \beta \gamma$ complexes, or Gi/o (Liebmann 2001, Marinissen \& Gutkind 2001). We found that blockade of G $\beta$ subunits by preincubation of cells with a $G \beta$ antibody abolished PTH-dependent ERK1/ERK2 activation in rat intestinal cells. In agreement with these observations, it was reported (Luttrell et al. 1996) that G $\beta \gamma$ subunitmediated formation of Shc-c-Src complexes and c-Src kinase activation are early events in Ras-dependent activation of MAP kinase via pertussis toxin-sensitive $G$ protein-coupled receptors. Nishida et al. (2000) reported that inhibition of the $\beta \gamma$ subunit attenuates hydrogen peroxide $\left(\mathrm{H}_{2} \mathrm{O}_{2}\right)$-induced ERK activation via c-Src in rat neonatal cardiomyocytes. c-Src can also activate Ras through the transactivation of the epidermal growth factor receptor and related receptors following stimulation of GPCRs coupled to either Gi or Gq (Della Rocca et al. 1997, Andreev et al. 2001, Shah \& Catt 2002).

In summary, the results of this work show that PTH activates c-Src in intestinal cells through conformational changes via $G$ proteins and a calcium-dependent modulation of tyrosine phosphorylation of the enzyme, and that PTH receptor activation leads via $\mathrm{G} \beta \gamma-\mathrm{C}-\mathrm{Src}$ to the phosphorylation of the MAP kinases, ERK1 and ERK2 (Fig. 8).

\section{Acknowledgements}

This research was supported by grants from the Agencia Nacional de Promoción Científica y Tecnológica, Consejo Nacional de Investigaciones Cientificas y Técnicas (CONICET), and Universidad Nacional del Sur, Argentina. The authors declare that there is no conflict of interest that would prejudice the impartiality of this scientific work.

\section{References}

Andreev J,Galisteo ML, Kranenburg O, Logan SK, Chiu ES, Okigaki M, Cary LA, Moolenaar WH \& Schlessinger J 2001 Src and Pyk2 mediate $\mathrm{G}$ protein-coupled receptor activation of epidermal growth factor receptor (EGFR) but are not required for coupling to the mitogen-activated protein (MAP) kinase signaling cascade. Journal of Biological Chemistry 276 20130-20135.

Balcueva EA, Wang Q, Hughes H, Kunsch C, Yu Z \& Robishaw JD 2000 Human $G$ protein gamma(11) and gamma(14) subtypes define a new functional subclass. Experimental Cell Research 257 310-319.

Betty M, Harnish SW, Rhodes KJ \& Cockett MI 1998 Distribution of heterotrimeric G-protein beta and gamma subunits in the rat brain. Neuroscience 85 475-486.

Bonaccorsi L, Luconi M, Forti G \& Baldi E 1995 Tyrosine kinase inhibition reduces the plateau phase of the calcium increase in response to progesterone in human sperm. FEBS Letters 364 83-86.

Bradford M 1976 A rapid and sensitive method for the quantification of microgram quantities of protein utilizing the principle of protein-dye binding. Analytical Biochemistry 72 248-254.

Broome MA \& Hunter T 1996 Requirement for c-Src catalytic activity and the SH3 domain in platelet-derived growth factor BB and epidermal growth factor mitogenic signaling. Journal of Biological Chemistry 271 16798-16806.

Brown MT \& Cooper JA 1996 Regulation, substrates and functions of Src. Biochimica et Biophysica Acta 1287 121-149.

Carragher NO, Fincham VJ, Riley D \& Frame MC 2001 Cleavage of focal adhesion kinase by different proteases during Src-regulated transformation and apoptosis. Distinct roles for calpain and caspases. Journal of Biological Chemistry 276 4270-4275.

Cary LA, Klinghoffer RA, Sachsenmaier C \& Cooper JA 2002 Src catalytic but not scaffolding function is needed for integrin-regulated tyrosine phosphorylation, cell migration, and cell spreading. Molecular and Cellular Biology 22 2427-2440.

Clapham DE \& Neer EJ 1997 G protein beta gamma subunits. Annual Review of Pharmacology and Toxicology 37 167-203. 
DellaRocca G, vanBiesen T, Daaka Y, Luttrell DK, Luttrell LM \& Lefkowitz RJ 1997 Ras-dependent mitogen-activated protein kinase activation by $\mathrm{G}$ protein-coupled receptors. Convergence of Gi- and Gq-mediated pathways on calcium/calmodulin, Pyk2, and Src kinase. Journal of Biological Chemistry 272 19125-19132.

Erpel T \& Courtneidge SA 1995 Src family protein tyrosine kinases and cellular signal transduction pathways. Current Opinion in Cell Biology 7 176-182.

Farndale R, Allan L \& Martin R. 1994 Adenylate cyclase and cAMP. In Signal Transduction, a Practical Approach, pp 75-103. Ed G Milligan. Oxford: Oxford University Press.

Fleming I, Fisslthaler B \& Busse R 1995 Calcium signaling in endothelial cells involves activation of tyrosine kinases and leads to activation of mitogen-activated protein kinases. Circulation Research $76522-529$.

Gentili C \& de Boland AR 2000 Age-related decline in mitogen-activated protein kinase phosphorylation in PTH-stimulated rat enterocytes. Experimental Gerontology 35 1003-1015.

Gentili C, Boland R \& de Boland AR 2001a PTH stimulates PLC $\beta$ and $\gamma$ isozymes in rat enterocytes: influence of ageing. Cellular Signaling 13 131-138.

Gentili C, Morelli S, Boland R \& de Boland AR $2001 b$ Parathyroid hormone activation of MAP kinase in rat duodenal cells is mediated by $3^{\prime}, 5^{\prime}$-cyclic AMP and $\mathrm{Ca}^{2+}$. Biochimica et Biophysica Acta 1540 201-212.

Gentili C, Picotto G, Morelli S, Boland R \& Russo de Boland A $2003 a$ Effect of ageing in the early biochemical signals elicited by PTH in intestinal cells. Biochimica et Biophysica Acta 1593 169-178.

Gentili C, Morelli S \& Russo de Boland A 2003b Characterization of $\mathrm{PTH} / \mathrm{PTHrP}$ receptor in rat duodenum: Effects of ageing. Journal of Cellular Biochemistry 88 1157-1167.

Hamm HE 1998 The many faces of G protein signalling. Journal of Biological Chemistry 273 669-672.

Ibitayo AI, Tsunoda Y, Nozu F, Owyang C \& Bitar KN 1998 Src kinase and PI 3-kinase as a transduction pathway in ceramide-induced contraction of colonic smooth muscle. American Journal of Physiology 275 G705-G711.

Izbicka E, Niewolna M, Yoneda T, Lowe C, Boyce B \& Mundy G 1994 c-Src expression and activity in MG-63 osteoblastic cells modulated by $\mathrm{PTH}$ but not required for $\mathrm{PTH}$-mediated adenylate cyclase response. Journal of Bone and Mineral Research 9 127-132.

Jamora C, Yamanouye N, Van Lint J, Laudenslager J, Vandenheede JR, Faulkner DJ \& Malhotra V 1999 G beta gamma-mediated regulation of Golgi organization is through the direct activation of protein kinase D. Cell 98 59-68.

Khare S, Bolt MJ, Wali RK, Skarosi SF, Roy HK, Niedziela S, Scaglione-Sewell B, Aquino B, Abraham C, Sitrin MD, Brasitus TA \& Bissonnette M 1997 1,25 Dihydroxyvitamin $D_{3}$ stimulates phospholipase C-gamma in rat colonocytes: role of c-Src in PLC-gamma activation. Journal of Clinical Investigation $\mathbf{9 9}$ 1831-1841.

Koch WJ, Hawes BE, Allen LF \& Lefkowitz RJ 1994 Direct evidence that Gi-coupled receptor stimulation of mitogen-activated protein kinase is mediated by $\mathrm{G}$ beta gamma activation of $\mathrm{p} 21$ ras. PNAS 91 12706-12710.

Laemmli UK 1970 Cleavage of structural proteins during the assembly of the head of bacteriophage T4. Nature 227 680-685.

Lee KM, Toscas K \& Villereal ML 1993 Inhibition of bradykininand thapsigargin-induced $\mathrm{Ca}^{2+}$ entry by tyrosine kinase inhibitors. Journal of Biological Chemistry 268 9945-9948.

Liebmann C 2001 Regulation of MAP kinase activity by peptide receptor signaling pathway: paradigms of multiplicity. Cellular Signaling 13 777-785.

Lin HC, Duncan JA, Kozasa T \& Gilman AG 1998 Sequestration of the $G$ protein beta gamma subunit complex inhibits receptor-mediated endocytosis. PNAS 95 5057-5060.
Liu JP, Yajima Y, Li H, Ackland S, Akita Y, Stewart J \& Kawashima S 1997 Molecular interactions between dynamin and G-protein beta gamma-subunits in neuroendocrine cells. Molecular and Cellular Endocrinology 132 61-71.

Luttrell LM, Hawes BE, van Biesen T, Luttrell DK, Lansing TJ \& Lefkowitz RJ 1996 Role of c-Src tyrosine kinase in G protein-coupled receptor- and $\mathrm{G}$ beta gamma subunit-mediated activation of mitogen-activated protein kinases. Journal of Biological Chemistry 271 19443-19450.

Luttrell LM, Della Rocca GJ, van Biesen T, Luttrell DK \& Lefkowitz RJ 1997 G beta gamma subunits mediate Src-dependent phosphorylation of the epidermal growth factor receptor. A scaffold for $\mathrm{G}$ protein-coupled receptor-mediated Ras activation. Journal of Biological Chemistry 272 4637-4644.

Ma YC, Huang J, Ali S, Lowry W \& Huang XY 2000 Src tyrosine kinase is a novel effector of $\mathrm{G}$ protein. Cell 102 635-646.

Marinissen MJ \& Gutkind JS 2001 G-protein-coupled receptors and signaling networks: emerging paradigms. Trends in Pharmacological Sciences B 22 368-376.

Marshall CJ 1995 Specificity of receptor tyrosine kinase signaling: transient versus sustained extracellular signal-regulated kinase activation. Cell 80 179-185.

Massheimer V, Boland R \& de Boland AR 1994 Rapid 1,25(OH) ${ }_{2} \mathrm{D}_{3}$ stimulation of calcium uptake by rat intestinal cells involves a dihydropyridine-sensitive cAMP-dependent pathway. Cell Signaling 6 299-304.

Massheimer V, Picotto G, Boland R \& de Boland AR 2000 Effect of aging on the mechanisms of PTH-induced calcium influx in rat intestinal cells. Journal of Cellular Physiology 182 429-437.

Morishita R, Shinohara H, Ueda H, Kato K \& Asano T 1999 High expression of the gamma 5 isoform of $\mathrm{G}$ protein in neuroepithelial cells and its replacement of the gamma 2 isoform during neuronal differentiation in the rat brain. Journal of Neurochemistry 73 2369-2374.

Neer EJ 1995 Heterotrimeric G proteins: organizers of transmembrane signals. Cell 80 249-257.

Niklinska BB, Yamada H, O’Shea JJ, June CH \& Ashwell JD 1992 Tyrosine kinase-regulated and inositol phosphate-independent $\mathrm{Ca}^{2+}$ elevation and mobilization in T cells. Journal of Biological Chemistry 267 7154-7159.

Nishida M, Maruyama Y, Tanaka R, Kontani K, Nagao T \& Kurose H 2000 Gai and $G \alpha o$ are target proteins of reactive oxygen species. Nature 408 492-495.

Parsons JT \& Parsons SJ 1997 Src family protein tyrosine kinases: cooperating with growth factor and adhesion signaling pathways. Current Opinion in Cell Biology 9 187-192.

Picotto G, Massheimer V \& Boland R 1997 Parathyroid hormone stimulates calcium influx and the cAMP messenger system in isolated rat duodenal cells. American Journal of Physiology 273 C1349-C1353.

Pitcher JA, Inglese J, Higgins JB, Arriza JL, Casey PJ, Kim C, Benovic JL, Kwatra MM, Caron MG \& Lefkowitz RJ 1992 Role of beta gamma subunits of $\mathrm{G}$ proteins in targeting the beta-adrenergic receptor kinase to membrane-bound receptors. Science 257 1264-1267.

Rhee SG \& Bae YS 1997 Regulation of phosphoinositide-specific phospholipase C isozymes. Journal of Biological Chemistry 272 15045-15048.

Roche S, Koegl M, Barone MV, Roussel MF \& Courtneidge SA 1995 DNA synthesis induced by some but not all growth factors requires Src family protein tyrosine kinases. Molecular and Cellular Biology 15 1102-1109.

Rosenblatt M, Kronenberg H \& Potts J 1989 Parathyroid hormone: physiology, chemistry, biosynthesis, secretion, metabolism and mode of action. In Endocrinology, pp 848-891. Ed LJ Degroot. Philadelphia: Saunders.

Schneider T, Igelmund P \& Hescheler J 1997 G protein interaction with $\mathrm{K}^{+}$and $\mathrm{Ca}^{2+}$ channels. Trends in Pharmacological Sciences 18 $8-11$. 
Schuller U, Lamp EC \& Schilling K 2001 Developmental expression of heterotrimeric G-proteins in the murine cerebellar cortex. Histochemistry and Cell Biology 116 149-159.

Shah B \& Catt KJ 2002 Calcium-independent activation of extracellularly regulated kinases 1 and 2 by angiotensin II in hepatic C9 cells: roles of protein kinase Cdelta, Src/proline-rich tyrosine kinase 2, and epidermal growth receptor trans-activation. Molecular Pharmacology 61 343-351.

Snedecor G \& Cochran W 1967 Statistical Methods, pp120-134. Ames, Iowa: Iowa State University Press.

Stow J \& Heimann K 1998 Vesicle budding on Golgi membranes: regulation by $\mathrm{G}$ proteins and myosin motors. Biochimica et Biophysica Acta 1404 161-171.

Sunahara RK, Dessauer CW \& Gilman AG 1996 Complexity and diversity of mammalian adenylyl cyclases. Annual Review of Pharmacology and Toxicology 36 461-480.

Tovey KC, Oldham K \& Whelam J 1974 A simple direct assay for cyclic AMP in plasma and other biological samples using an improved competitive protein binding technique. Clinica Chimica Acta 56 221-223.

Tsunoda Y, Yoshida H, Africa L, Steil GJ \& Owyang C 1996 Src kinase pathways in extracellular $\mathrm{Ca}^{2+}$-dependent pancreatic enzyme secretion. Biochemical and Biophysical Research Communications 227 876-884.

Weiser MM 1973 Intestinal epithelial cell surface membrane glycoprotein synthesis. I. An indicator of cellular differentiation. Journal of Biological Chemistry 248 2536-2541.

Xu W, Harrison SC \& Eck MJ 1997 Three-dimensional structure of the tyrosine kinase c-Src. Nature 385 595-602.

Xu W, Doshi A, Lei M, Eck M \& Harrinson S 1999 Crystal structures of c-Src reveal features of its autoinhibitory mechanism. Molecular Cell 3 629-638.

Received 11 October 2005

Accepted 26 October 2005 